\title{
Climate Change Anticipation on Supporting Capacity of Fishing Environment in the Coastal Area of Tanjungmas Semarang City
}

\author{
Indah Kurniasih Wahyu Sari ${ }^{1, *}$, Sudharto P.Hadi ${ }^{2}$ \\ ${ }^{1}$ Master Program of Environmental Science, School of Postgraduate Studies Diponegoro University, Semarang-Indonesia \\ ${ }^{2}$ Doctoral Program of Environmental Science, School of Postgraduate Studies Diponegoro University, Semarang-Indonesia
}

\begin{abstract}
Climate change is no longer a debate about its existence but already a problem shared between communities, between agencies, between countries even global for handling serious because so many aspects of life and the environment is affected, especially for communities in coastal environments This climate change is a threat to the Earth, because it can affect all aspects of life and will damage the balance of life of Earth Climate change happens slowly in a fairly long period of time and it is a change that is hard to avoid. These Phenomena will give effect to the various facets of life. Semarang as areas located to Java and bordering the Java Sea are at high risk exposed to the impacts of climate change Also not a few residents of the city of Semarang who settled in the northern part of the city of Semarang and also have a livelihood as farmers/peasants and fishermen Many industrial centers or attractions that are prone to impacted by climate change. Thus, the anticipation of climate change on resources support neighborhood of fishermen in the coastal area of Tanjungmas Semarang interesting for further review. This study aims to find out more the influence of climate change on the environment of fishing identify potential danger due to the impacts of climate change on coastal areas of Tanjungmas Semarang The research was conducted through surveys, interviews and field observation without a list of questions to obtain primary and secondary data As for the analys is undertaken, namely the analysis of climate change on the coastal environment, the analys is of productivity of fishermen as well as the analysis of the likelihood of disaster risk at the coast due to climate change. From the results of the study the occurrence of sea rise as one of the indicators of climate change in the coastal City of Semarang to reach $0.8 \mathrm{~mm} / \mathrm{year}$ and average soil degradation that ranged between $5-12 \mathrm{~cm} /$ year cause most coastal communities as well as the social life of the agricultural areas of its economy relies on the resources becoming increasingly erratic.
\end{abstract}

\section{Introduction}

Climate change is one of the natural phenomena where there is a change in the value of climate elements either naturally or accelerated by human activity on earth. Since the industrial revolution began, it has caused increase to global temperature. Currently, climate change is no longer a matter of debate about its existence but has become a common problem between communities, between agencies, between countries and even global to get handled because so many aspect of life get affected, especially fishery sector. Productivity and progressivity of fishery sector is affected by many factors, especially climate change and anomaly.

Government concerns related to adaptation and mitigation to climate change are regulated in the Minister of Home Affairs Regulation Number 30 Year 2010 About Guidelines for Resource Management in Marine Areas, in section four article 18 affirmed that the Regional Government in planning the management of resources in the marine areas, shall include materials containing adaptation effort and mitigation of impact from climate change. Furthermore, referred in article 19 that adaptation and mitigation of climate change is done by involving the government, regional government and/or society.

According to [1] climate change occurs around the world and has a significant impact on the fisheries sector in Java. Demand for fishery products increase in line with population growth and nutritional needs but productivity is relatively inelastic to meet the demand. The impact of climate change has been detected since 1980 to 2008 either ecologically or oceanographically. Sea surface temperature are positively detected experiencing anomalies, extreme season change have caused change to sea breeze and wave height, and so forth.

As an archipelagic country, Indonesia is very vulnerable to the impacts of climate change. With the condition as a developing country, our ability to adapt to climate change has not been as good as developed countries [2]. The City of Semarang as an area located in the north of Java Island and directly adjacent to Java Sea has a high risk to get affected by climate change. Not a few residents of Semarang City who live in the northern part of Semarang City that works as a farmer and fisherman. Many industrial center or tourist attractions are prone to climate change impact [3].

\footnotetext{
*Corresponding author: indahkurniasihw@gmail.com
} 
Climate change phenomena has actually happened and currently still going on today until the upcoming times. In principle, climate change occurs because some climate elements intensity deviates from the normal condition towards a certain direction.

One of climate change impacts is the high rainfall occurring over a period of time. The presence of high rainfall in the city of Semarang can be a threat to coastal areas like Tanjungmas. This is because rain water flows from the higher topography such as Semarang hills to the lower topography like coastal areas through the river flow [4]. If the river condition can't contain the water volume optimally then the potential for the river to overflow to the land will increase. For Tanjungmas area is also flowed by the river flow which can potentially overflow the surrounding area at any time. On the other side of Tanjungmas located in the Semarang city coast is also prone to the threat of rising sea levels. Some locations become routine areas that are constantly inundated by flood and every year the height of the flood is increasing. Based on the results of the Indonesian fishermen condition and the existence of climate change that occurred, as a concrete solution in providing support to the people and the environment, it is necessary to have a proper study for the people in adapting to the change. Proper strategies implementation for dealing with climate change needs to be prepared so that people are not vulnerable to the rate of change [5]. Therefore the fundamental question of this research is, How to anticipate fishermen people in the coastal areas in the face of climate change?

Based on the above background, the problems to be discussed in this research are:

1. What is the effect of climate change to the supporting power of the coastal areas environment?

2. What is the adaptation strategy of the fishermen in the coastal area of Tanjungmas in facing the climate change impacts?

Based on the problems above, the purpose of this study are: (1). Analyzing the effect of climate change to the socio-economic condition of Tanjungmas fishermen, (2). Identify adaptation strategies undertaken by Tanjungmas fishermen in facing the climate change impacts.

This research is expected to provide benefits for various parties [6] : (1). For academics, this research can be a further reference on the adaptation of fishermen to climate change in the coastal area of Tanjungmas in particular, (2). For the people, the results of these study can be models of adaptation patterns that can be useful for the development of adaptation and mitigation of climate change in coastal areas, (3). For the government. This research can be used as information that can influence decision making that can determines development policy, especially development in fishery sector.

\section{Theoretical Approach}

On climate change which states "Climate change means a change of climate which is attributed directly or indirectly to human activities that alters the composition of the global atmosphere and which is in addition to natural climate variability observed over comparable time periods. "[6] explains that climate change is a change in elements over a long period of time (50-100 years) that is influenced by human activity that produce greenhouse gas (GHG) emission. From Diposaptono explanation, it is seen that climate anomaly that occured in a short time is not referred to as climate change. When interpreting climate change with both definitions, climate change is a change of climatic elements that occurred over a long period of time and can be compared. For example, [7] by observing the temperature data and seeing that there is a tendency to rise over time and the fluctuation is getting bigger, or climate anomaly has become more frequent than the previous time period, it can be said that climate change have occurred.

Explained that climate change originating from a global level where global warming is caused by the increase of carbon emission $\left(\mathrm{CO}_{2}\right)$ that can melt ice at the poles and increase the sea levels. Satria also added, global warming occurred due to the increase of global temperature because of greenhouse effect caused by the increasing emission of gases such as carbon dioxide $\left(\mathrm{CO}_{2}\right)$, Methane $\left(\mathrm{CH}_{4}\right)$, and $\mathrm{CFC}$, trapping the solar energy in the earth's atmosphere. Thus, global climate change is the accumulation of economic activity derived from fossil energy and worsening deforestation.

\section{Methods}

This study is an empirical study on climate change anticipation to supporting power of the fishermen environment in Tanjungmas coastal area of Semarang City. The method used to analyze the data in this study is a qualitative approach descriptively. Qualitative data analysis is done by interview to the fishermen subjects and key-person.

\subsection{Impacts of Climate Change on Fisherman's Environment}

Given the impact of climate change in Indonesia, the most vulnerable category of people are fishermen, especially coastal people. Basically, fishermen in everyday activity are very dependent on nature. Drastic change to nature that are difficult to anticipate, will further add panic to natural changes that will eliminate their catch. Fishermen live in uncertainty of their work, as they depend on nature (season and weather). With the impact of climate change that directly affects the environment, the uncertainty is increasing to the livelihood aspects of fishermen.

Climate change also affects the social, cultural, and economic conditions of fishermen. Indicators and impacts from climate change to the fishermen environment are as follows [8] : 
1. Indicators of seasonal patterns change and wind pattern adopted by fishermen make it difficult for the fishermen to predict sea condition, disrupt fishing activity and safety of fishermen.

2. The disappearance of some animal that mark the change of the season, the shifting of the season start and end time, untrackable wind and waves that have been believed as the marker of the beginning and the end of a season, the changing speed of the wind in certain seasons as well as the period of wind and waves in a certain seasons have an impact on the uncertainty to sail.

\subsection{Environmental Condition of Coastal Fishermen}

Explains that coastal society is groups of people who together inhabit coastal areas and have a distinctive culture associated with the dependence on the utilization of coastal resources. Furthermore, it is also explained that coastal people are not only fishermen, but also fish farmers, fish processors and even fish traders. Coastal people have economic system that are not much different with the fishermen in general [9]. Coastal people solidarity is very strong due to the geographical condition that make them have to struggle together to survive in all aspect of life associated with the sea. Visible from the transportation, logistic entry, and work source as well as largest natural resources comes from the sea.

Fishermen who work in the sea are often confronted with uncertainty and ecological conditions that are hard to control. Fishermen are different from farmers, where they are faced with a difficult ecological situation to control their products considering capture fisheries are an open access so that fishermen have to move around and the risks that must be faced are greater than that faced by farmers. It is also explained that, fishermen also have to deal with the harsh marine life that makes them generally tough, firm, and open, which distinguishes them with farmers [10].

Characteristic of the small fishermen is that they are still using traditional technology, because of economical condition, they can not afford it. Usually the small fishermen are called gurem fishermen, where they live subsistent only to fulfill basic daily needs. However in their development, small fishermen also commercialize their catch for sale, they usually submitted their catch to the bosses. The relationship between fishermen with their bosses has a patron-client bond to avoid the threat such as reducing emissions or reducing flood impact by building embankment.

Adaptation concept declared by [9] cited by [11] is one part of cultural evolution process, a process that includes a series of people efforts to adapt or giving respond to the change of physical and social environment that happened temporally. Such responsive behavior allow them to organize certain systems for the action or behavior.
Here is the adaptation strategies undertaken by the fishermen to face climate change, namely:

1. In the economic aspect, emerges a strategy of livelihood shifting and diversification.

2. In the technical and technological aspect of capture, there are strategies of diversifying fish catching gear and changing the fishing areas.

3. In the socio-cultural aspect, there is a strategy to utilize social relations and mobilizing family members.

\section{Result and Discussion}

This research is conducted in the coastal area of Tanjungmas, North Semarang sub-district, to see how the anticipation strategy caused by climate change to the environmental supporting capacity of fishermen in Semarang city. Fishermen who become respondents in this research are those who still use traditional fishing gear and small boat. According to the majority of respondents, the condition of fishermen today is only sufficient to eat and must have side jobs. While the previous conditions are more sufficient for fishermen compared to the current lacking conditions for the fishermen who are mostly small fishermen[9].

\section{Geographical and Nature Condition}

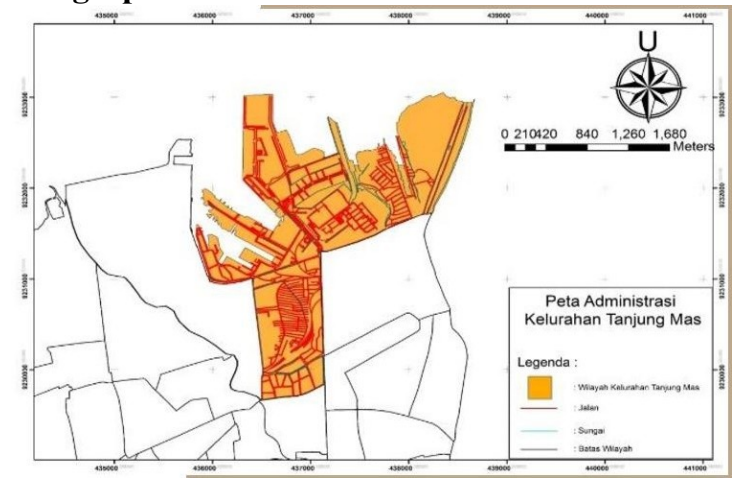

Fig. 1. Semarang Utara Sub-Distric Map

Tanjungmas urban village located in the northern sub-district of Semarang, covering an area of $323,782 \mathrm{Ha}$ consists of 271,782 Ha dried lands (yard/building/emplacement) and $52 \mathrm{Ha}$ wetlands (embankment). Tanjungmas urban village includes two neighborhood areas, namely Tambak Lorok village in the north and Sidodadi village in the south. Tanjungmas urban village is one of many urban villages which is included in the north semarang sub-district. The role of this area with high activity is because of its high access value, strategic location, close to the activity center, the city center and the transportation hub. One of the areas in Tanjungmas is Tambak Lorok. The graph above shows the total population based on the number of men and women in Tambak Lorok. The majority of Tambak Lorok residents are immigrants who moved because of their work in Tambak Lorok. For more detailed data 
based on per hamlet (RT) and average income per neighbourhood (RW).

Tambak Lorok area is located in Tanjungmas urban village, North Semarang Sub-district. This area is located on the coast of Java Sea which is crossed by Kali Banger. This area is famous for fishing settlements since 1950. Tambak Lorok area consists of 5 neighborhood that is RW $12,13,14,15,16$. With an area of 46.8 Ha. Height 0,5 Above Mean Sea Level (AMSL). The geographical location of Tambak Lorok Estate is viewed from Semarang City, BWK III of Semarang City, where most of the land used as settlements. Physically, the area of Tambak Lorok is adjacent to:

North : Java Sea

East : Kali Banger

South : North Artery Road

West : Steam and Gas Powered Power Plant

Table 1. Total Population by Gender and Age Group

\begin{tabular}{cccc}
\hline Age(Years) & Male & Female & Total \\
\hline $0-4$ & 1.250 & 1.223 & 2.473 \\
$5-9$ & 1.238 & 1.183 & 2.421 \\
$10-14$ & 1.194 & 1.270 & 2.464 \\
$15-19$ & 1.320 & 1.394 & 2.714 \\
$20-24$ & 1.301 & 1.719 & 3.020 \\
$25-29$ & 1.585 & 1.829 & 3.414 \\
$30-34$ & 1.340 & 1.494 & 2.834 \\
$35-39$ & 1.095 & 1.251 & 2.346 \\
$40-44$ & 1.012 & 1.103 & 2.115 \\
$45-49$ & 816 & 1.106 & 1.922 \\
$50-59$ & 785 & 963 & 1.748 \\
$60-64$ & 376 & 384 & 760 \\
$>65$ & 119 & 195 & 314 \\
Total & 13.431 & 15.114 & 28.545 \\
\hline
\end{tabular}

Tanjungmas coastal area, North Semarang Sub-district, has a fairly high number of poor people compared to other areas. From the data obtained shows that the level of poor people in North Semarang has the second highest number after the sub-district of West Semarang. For North Semarang sub-district, the majority of the poor people are in the Tanjungmas urban village. Whereas, if viewed from the potential, Northern Semarang is one part of Semarang city that has an economic activities that are developing due to the industrial and trading area. By looking at the condition of residency in Tambak Lorok, it can be categorized into the poor people in Semarang city. This condition is quite alarming because many poor people who must face the climate change disaster that requires them to make various adaptation efforts[12].

\subsection{Population and Livelihood}

The people of Tambak Lorok village, as much as $80 \%$ is people with income as fishermen, the rest are factory workers and construction workers. Men as heads of families are at sea assisted by their teenage and adult boys. Most fishermen here use private boats with a group system or use a rented vessel with a payment model through revenue share for the catch obtained. Most of the fishermen's catch is sold directly to the broker who will sell the products outside of Tambak Lorok area especially to Semarang City and its surroundings as well as to the restaurants that wanted certain quality and type. A small portion of the catch is sold directly to the market in Tambak Lorok, at the restaurant.

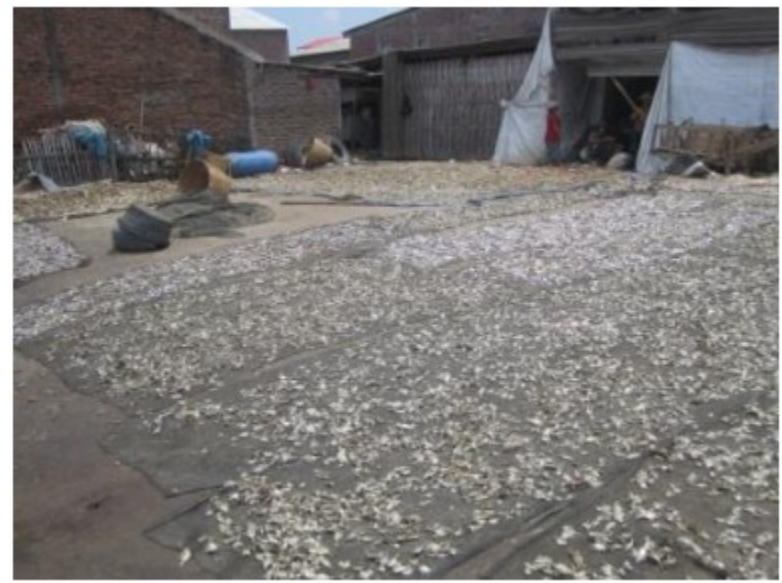

Fig. 2. Fishermen's catch

So most of the fish and other catch in TPI is the catch from fishermen with bigger boats owned by fishermen outside of Tambak Lorok. This is because most fishermen in Tambak Lorok use a relatively small boat with a smaller assets of course, so that the effect on the range or distance of the ocean that can be sailed and ultimately affect the quality and size of the catch. The people that works as fishermen, laborers, and fish traders have an average income of Rp.500.000 Rp.1.500.000 / month. Every day the fishermen get a gross income from the sale of the catch of Rp. 500.000 then it was cut to buy diesel fuel for the ship ammounting Rp.300.000.

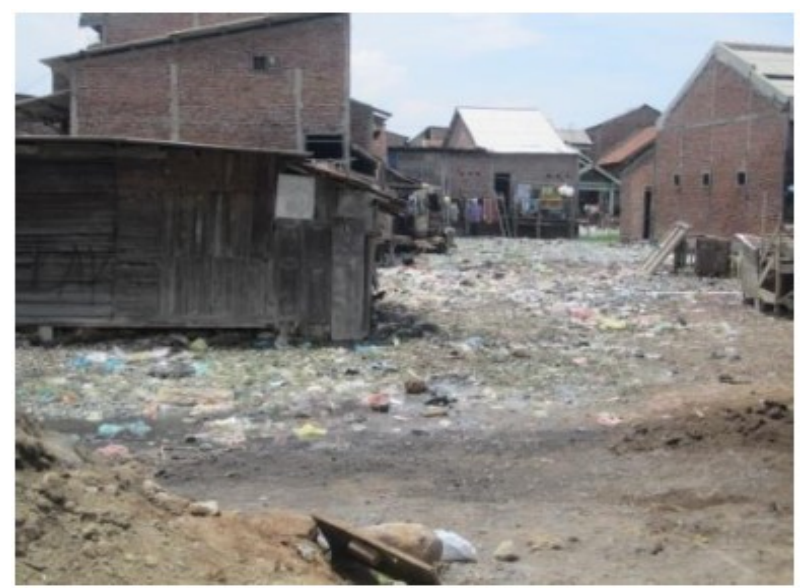

Fig. 3. Environmental Condition of Tanjungmas Fishermen 


\subsection{Economic Condition of Tanjungmas Fishermen Environment}

The existing condition of existing settlements in Tambak Lorok village strongly does not support the economic growth around. Bad road conditions, poor drainage systems and litterring problems are the problems in this village. This is due to the problems that exist in Kampung Tambak Lorok, such as flood which always becomes an integral part of this area caused the condition of settlement in Tambak Lorok getting worse and slum. The condition of this slum occurs due to the deterioration of environmental quality.

In addition, there is no availability of adequate facilities and infrastructure that will affect the existing economic activities in Tambak Lorok village. Furthermore, the problems that exist in Tambak Lorok village studies in Tambak Lorok village are as follow.

Tabele 2. Number and Percentage of Respondents by Age

\begin{tabular}{llc}
\hline \multicolumn{1}{c}{ Age } & \multicolumn{2}{c}{ Respondent } \\
\cline { 2 - 3 } & $\mathbf{n}$ & $\mathbf{\%}$ \\
\hline Young ( 18-30 Years) & 6 & 13,3 \\
Adult (31-50 Years) & 20 & 73,3 \\
Old (>50 Years) & 4 & 13,3 \\
Total & 30 & 100,0 \\
\hline
\end{tabular}

Natural resources potential in the form of sea catch, including squid, shrimp, shellfish, red snapper, lotung. Infrastructure, many environment access are bad due to frequent rob, the boats are still traditional, communal washroom, electricity is available, the source of clean water is still limited. Geographic conditions with flat topography $(0-2 \%)$, while the mean maximum tidal height is $0.40-0.60 \mathrm{~m}$. Based on the zoning of the coastal area of Semarang City, Tambak Lorok belongs to the Tanjungmas village area located in the subsident Zone of $>0.20 \mathrm{~m}$ per year. This area is strongly influenced by tidal sea water. Almost the entire residential area was inundated by the time the sea was in high tide[14]. This makes residents periodically raise peil (ground floor height points) of their home building.

Table 3. Number and Percentage of Respondents by Level of Education

\begin{tabular}{llc}
\hline \multicolumn{1}{c}{ Education level } & \multicolumn{2}{c}{$\begin{array}{c}\text { Respondent } \\
\mathbf{\%}\end{array}$} \\
\hline $\begin{array}{l}\text { Low } \\
\text { (Uneducated or Elementary }\end{array}$ & 20 & 80,0 \\
$\begin{array}{l}\text { School Graduate equivalent) } \\
\text { Medium }\end{array}$ & 10 & 20,0 \\
$\begin{array}{l}\text { (Junior High School Graduate / } \\
\text { equivalent) }\end{array}$ & & \\
$\begin{array}{l}\text { High } \\
\text { (Senior High School Graduate / } \\
\text { equivalent) } \\
\text { Total }\end{array}$ & 0 & 00,0 \\
\hline
\end{tabular}

Table 4. Number and Percentage of Respondents Based on Duration of Work as Fishermen

\begin{tabular}{llr}
\hline Duration as Fishermen & \multicolumn{2}{c}{ Respondent } \\
\cline { 2 - 3 } & $\mathbf{n}$ & $\mathbf{\%}$ \\
\hline Low (0-10 years) & 2 & 6,7 \\
Medium (11-20 years) & 10 & 33,3 \\
High ( $>21$ years) & 18 & 60,0 \\
Total & 30 & 100,0 \\
\hline
\end{tabular}

The table above shows the respondents of Tanjungmas People types of work. The majority of people have odd jobs, which are temporary or alternating jobs. Then followed by traders (majority of fish traders), unemployed, services, labor (for the industry around), and fishermen. Although the smallest number are fishermen, Tanjungmas is also called village of fishermen. The researcher assumes this is because the odd jobs, services, laborers, unemployed, and the traders will become fishermen (in the sense of fishing) during their free time to supplement their income so that there are "impromptu fishermen" at certain times[13].

\section{Respondent Characteristic Age of Respondents}

Age is the range of years the respondent was born until the year at the time of the study. The number and percentage of respondents by age can be seen in table. 5 . The age of respondents varied, the lowest ranging from 25 years and the highest 54 years. The data in table. 3 . shows that the average age of respondents is 39 years out of a total of 30 respondents. Young respondents are 4 people or about 13.3 percent, adults are 22 people or about 73.3 percent, and elderly are 4 people or about 13.3 percent. In conclusion, most of the fishermen respondents in Tanjungmas urban areas have more adults than the young and old age category.

\section{Education of Respondents}

Respondent education is the highest level of education ever pursued by respondents. The number and percentage of education level of respondents can be seen in table. 6. In the table, it is seen that the distribution is not evenly distributed because it is the condition of fishermen in Tanjungmas village with maximum education only up to junior high school and no senior high school or university level.

Respondents with low education category were 24 people or 80 percent, medium category was 6 people or 20 percent, and none were highly educated. The conclusion that can be taken is the average of respondent of fishermen in Tanjungmas Urban area many people categorized as low level of education and nil for the category of respondents with high education [15].

\section{Working Duration as Fishermen}

Working duration as fishermen is the span of time in the early years of respondents working as fishermen until research is started. Respondents who are categorized as low 2 people or 6.7 percent, while 10 people or 33.3 
percent and 18 people or 60 percent of the total of 30 respondents. The conclusion that can be taken is that most of the respondents are categorized have been working as fishermen for more than 20 years.

\subsection{Climate change and its impact on the environmental carrying capacity of fishermen}

Climate change also affects the social, cultural and economic conditions of fishermen. Indicators and impacts of climate change on social, cultural and economic fishing are:

1. Changes in seasonal patterns (the shifting of starting time and the end of the season) and the pattern of the wind adopted by fishermen make it difficult for fishermen to predict the sea condition, disrupt fishing activities and safety of fishermen. To understand climate change historically both the rate and impact of climate change occurring in Tanjungmas Urban Village on its socioeconomic condition.

2. Influence the fishermen's income level from fishing. Climate change that is happening up to now is considered by society affecting their income in fishery sector. People feel that their income since climate change that started from 2000 until now, decrease their income.

3. Fisherman's income, if only sourced from fishing alone will tend to show low per capita income. The fishermen responding to the impact of climate change that occurs and fish conditions that are uncertain, they work around it by doing additional work outside the fishery sector.

\subsection{Climate Change Indicators on Ecological Aspects}

Global climate change has resulted in enormous losses at the local level. Climate change impacts on all sectors, especially coastal areas.

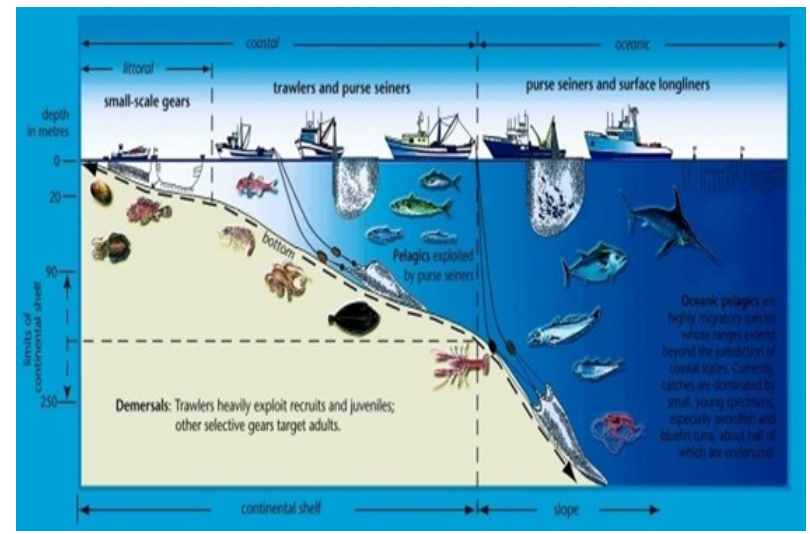

Fig. 4. Fishing paths

(1) Fishing Path I as referred to in Article 3 letter a. shall consist of :

Fishing lane IA, covering coastal waters up to 2 (two) nautical miles measured from sea level at lowest tide; and
Fishing lane IB, covering coastal waters beyond 2 (two) nautical miles up to 4 (four) nautical miles.

(2) Fishing lane II as referred to in Article 3 letter b, covering waters outside Fishing Lane I up to 12 (twelve) nautical miles measured from sea level at lowest tide.

(3) Fishing lane III as referred to in Article 3 letter c, covers ZEEI and waters off fishing lane II.

\subsection{Anticipating Climate Change on Climate and Weather Conditions}

Semarang City has a tropical climate and there are two seasons, the dry season and the rainy season which has a turnover cycle every six (6) months. The year-round rainfall with average annual rainfall varies about 902 $\mathrm{mm}$ each month with maximum monthly rainfall occurring in November with rainfall of $1,971 \mathrm{~mm}$. Semarang City on the coastal area has an air temperature ranging from $25.80 \mathrm{c}$ to $29.30 \mathrm{c}$. Semarang city has air humidity varies between $62-84 \%$. While the wind direction mostly moves from the southeast to the northwest with an average speed of $5.7 \mathrm{~km} /[1]$.

\begin{tabular}{|c|c|c|}
\hline No & Year & mm/year \\
\hline 1 & 2010 & 1.845 \\
\hline 2 & 2011 & 14.349 \\
\hline 3 & 2012 & 10.822 \\
\hline 4 & 2013 & 10.822 \\
\hline 5 & 2014 & 10.544 \\
\hline
\end{tabular}

The rainfall condition in Semarang in 2010-2015 has fluctuated with the highest rainfall in 2011 with an average rainfall of $14,349 \mathrm{~mm} /$ year. The lowest rainfall in 2010 with an average rainfall of 1,845 mm / year. Factors that affect the average value of rainfall per year is:

1. Latitude factor causes the difference in the quantity of rainfall, the lower the latitude the higher the rainfall potential is received, because in the lower latitudes the temperature is greater than the temperature at high latitudes, this high temperature will cause high evaporation, Then it will rain by condensation first.

2. Altitude factor, The lower the altitude where the more potential rainfall received, because in general the lower the altitude, the higher the temperature in the area.

3. The distance from the water source (evaporation), the closer the place will increase the rainfall potential.

4. Wind direction, the wind that passes through the evaporating source will bring water vapor, the farther the area from the water source the rainfall potential will decrease. 


\section{Conclusion}

The anticipation that fishermen have in coping with climate change is to mobilize family members. Fishermen in Tanjungmas usually mobilize or include family members in the work. Many fishermen in Tanjungmas take their sons who are on holiday or relatives to work together to catch fish. This is done for the efficiency of paid labor and unpaid family labor. In fishing with net there are some fishermen who invite family members to sail to the sea, besides fishermen's wife also have side jobs to help husband in fulfilling requirement such as selling processed food from fish, or helping husband take beach sand for building, make cracker, Shrimp paste and there are also looking for pangsik (a kind of shell attached to the coral sea).

Processed foods from fish that are usually sold are fish meatballs, fish crackers, and shrimp paste. Per day usually fishermen's wife can rack up money ranging from Rp. 30,000, to Rp.60.000, from the sale. Fisherman's wife can usually pocket the income Rp.70,000, - per kilogram from the manufacture of shrimp paste and fish crackers. The last job of the fisherman's wife is to search for pangsik which predominantly found in coral, the selling price per kilogram of which is usually Rp.70,000, - which will be used for processed food.

\section{References}

1. Badan Pusat Statistik Jawa Tengah. Jawa tengah Dalam Angka (2016)

2. Dasanto, Bambang Dwi. Jurnal Hidrosfir Indonesia.Vol 5 No 2 Hal 43-53

3. Fauzi, Akhmad. Ekonomi Sumbe Daya Alam dan Lingkungan. Jakarta : Gramedia Pustaka.(2006)

4. P. Manurung, J. Ananto, A. Restu, R. Marni, dan S. Barlianto, Seminar Nasional Pengaruh Global
Warming terhadap Pesisir dan Pulau-Pulau Kecil Ditinjau dari Kenaikan Permukaan Air Laut dan Banjir, Jakarta.(2002)

5. Menteri permukiman dan Prasanrana Wilayah. Tinjauan Aspek Penataan Ruang Dalam Pengelolaan Wilayah Laut dan Pesisir, Seminar Umum Dies Natalies ITS ke-43, (2003)

6. P.H, Nikijuluw Victor. Politik Ekonomi Perikanan. PT Fery Agung Corporation (FERACO): Jakarta.(2005)

7. V.P.H, Nikijuluw. Rezim Pengelolaan Sumberdaya Perikanan. Jakarta : P3R.(2002)

8. Pomeroy, Robert, Len Garces, Micahel Pido, Geronimo Silvestre. Journal of Elsevier: Marine Policy Vol 34: 298-308.(2009)

9. J. G., Pope, D. S., MacDonald, N., Daan, J. D. Reynolds, and S. Jennings. ICES Journal of Marine Science, 57, 689-696 (2000).

10. R., Rositasari, W.B. Setiawan, I.H. Supriadi, Hasanuddin, and B. Prayuda. Jurnal Ilmu dan Teknologi Kelautan Tropis, Vol. 3, No. 1, Hal. 5264 (2011)

11. Satuan Tugas Walikota Untuk Perubahan Iklim, Risiko Bencana \& Masyarakat Miskin Perkotaan, Laporan Perubahan Iklim DKI Jakarta bekerjasama dengan World Bank, Jakarta (2011)

12. Statistik Perikanan Kota Semarang, Pemkot Semarang, Dinas Perikanan.(2016)

13. Suparmoko. Ekonomi Sumberdaya Alam dan Lingkungan: Suatu Pendekatan Teoritis. Yogyakarta : BPFE.(2008)

14. Susandi, Armi; Herlianti, Indriani, Dampak Perubahan Iklim terhadap Ketinggian Muka Laut di Wilayah Banjarmasin, Institut Teknologi Bandung, Bandung. (2008)

15. A.D., Wirakusumah,. dan S. Lubis, Seminar Nasional Pengaruh Global Warming terhadap Pesisir dan PuIau-Pulau Kecil Ditinjau dari Kenaikan Permukaan Air Laut dan Banjir, Jakarta (2002). 